\title{
HUBUNGAN ANTARA PARTISIPASI MASYARAKAT, PEMBENTUKAN UNDANG-UNDANG DAN JUDICIAL REVIEW
}

\author{
Riza Multazam Luthfy \\ Universitas Islam Negeri Sunan Ampel Surabayal \\ J. Ahmad Yani No. I 17, Kota Surabaya, Jawa Timur 60237| \\ rizamultazam@uinsby.ac.id
}

\begin{abstract}
Community participation in national and state life today is an important study. This is because in a democratic country, public policy cannot be separated from public participation. This study seeks to discuss the relationship between community participation, the making of Act and the implementation of judicial review. The results showed that: (I) Public participation in the making of Act and the implementation of judicial review can: (a) Provide a better basis for public policy making in creating good governance. (b) Increase citizens' trust in the executive and legislative branches. (c) Save human resources, because with the involvement of the community in public policy making, the resources used in public policy socialization can be minimized. (2). Community participation in evaluating Act becomes an important activity, in order to establish control whether an Act is in accordance with its objectives or not. The public can submit a judicial review to the Supreme Court (MA) or the Constitutional Court (MK) if they judge that their rights have been impaired by certain Act. (3). The relationship between community participation and the making of Act and the implementation of judicial review is very close. Without community participation, the Act produced does not reflect the interests of the community and only prioritizes the interests of certain groups. The Constitutional Court (MK) and the Supreme Court (MA) will not conduct a judicial review if there is no request from the public.
\end{abstract}

Keywords: Community Participation, Making of Act, Judicial Review.

Abstrak: Partisipasi masyarakat dalam kehidupan berbangsa dan bernegara dewasa ini menjadi kajian penting. Hal ini dikarenakan bahwa dalam negara demokrasi, kebijakan publik tidak bisa dilepaskan dari partisipasi masyarakat. Penelitian ini berusaha membahas hubungan 
antara partisipasi masyarakat, pembentukan Undang-Undang dan pelaksanaan judicial review. Hasil penelitian menunjukkan bahwa: (I) Partisipasi masyarakat dalam pembentukan Undang-Undang dan pelaksanaan judicial review dapat: (a) Memberikan landasan yang lebih baik untuk pembuatan kebijakan publik dalam menciptakan suatu good governance. (b) Meningkatkan kepercayaan warga kepada eksekutif dan legislatif. (c) Efisiensi sumber daya manusia, sebab dengan keterlibatan masyarakat dalam pembuatan kebijakan publik, maka sumber daya yang digunakan dalam sosialisasi kebijakan publik dapat diminimalisir. (2). Partisipasi masyarakat dalam mengevaluasi Undang-Undang menjadi satu kegiatan penting, demi mengadakan kontrol apakah sebuah Undang-Undang sudah sesuai dengan tujuannya atau belum. Masyarakat dapat mengajukan judicial review kepada MA atau MK apabila merasa haknya dirugikan oleh Undang-Undang tertentu. (3). Hubungan antara partisipasi masyarakat dengan pembentukan UndangUndang dan pelaksanaan judicial review sangatlah erat. Tanpa partisipasi masyarakat, Undang-Undang yang dihasilkan kurang mencerminkan kepentingan masyarakat dan hanya mengutamakan kepentingan segelintir orang. Adapun MK dan MA tidak akan melakukan judicial review jika tidak ada permintaan dari masyarakat.

Kata Kunci: Partisipasi Masyarakat, Pembentukan Undang-Undang, Judicial Review.

\section{Pendahuluan}

Dengan dibukanya keran demokrasi selebar-lebarnya, partisipasi masyarakat mendapatkan posisinya yang sedemikian rupa. Partisipasi masyarakat digaungkan oleh kaum penjunjung demokrasi setelah beberapa dasawarsa mengalami keterpurukan, di mana sejarah kelam negara Indonesia mengindikasikan bahwa Orde Baru selalu berusaha mengebirinya. Meski belum sepenuhnya mencapai posisi ideal, partisipasi masyarakat mulai digalakkan demi melakukan pengawasan terhadap jalannya pemerintahan.

Kewenangan para anggota legislatif dalam menerbitkan Undang-Undang seringkali disalahgunakan. DPR yang merupakan representasi dari pemenang dalam pemilu kerap digunakan untuk menampung kepentingan-kepentingan yang dimiliki oleh partai yang diusung. Alih-alih menyampaikan aspirasi rakyat, anggota 
DPR malah mengejar target individu dan partai. Akibatnya, Undang-Undang yang dihasilkan masih sangat jauh dari harapan. Apa yang menjadi produk mereka ternyata kurang mencerminkan kepentingan masyarakat, karena hanya mengutamakan kepentingan segelintir orang.

Dalam pandangan Saldi Isra, fraksi selalu dimanfaatkan sebagai sarana paling strategis oleh berbagai kepentingan demi melumpuhkan beragam bentuk pemikiran kritis yang berkembang di DPR. Padahal, salah satu tujuan pembentukan fraksi yaitu optimalisasi penggunaan hak DPR. Selain itu, walaupun mempunyai kedudukan konstitusional yang sangat kuat, DPR masih merasa kesulitan untuk keluar dari kepentingan politik pemerintah. ${ }^{1}$

Para anggota DPR kerap menunjukkan beberapa perilaku yang kurang bertanggung jawab, semisal malas menghadiri agenda rapat, tidak tepat waktu ketika menghadiri persidangan, tidak memiliki kepekaan atau kepedulian, serta tidak berusaha meningkatkan kualitas diri. Selain menyebabkan anggota DPR kurang mampu beradaptasi dengan persoalan riil yang dihadapi masyarakat, hal ini juga melahirkan kesenjangan antara pengetahuan mereka dengan persoalan riil tersebut. Akibatnya, muncul proses alienasi anggota DPR dengan lingkungan sosial masyarakat yang telah mengusung dan memilih mereka. Anggota DPR kurang mampu melaksanakan 'amanah' dan walaupun tetap menghadiri agenda rapat, sayangnya mereka sama sekali tidak memperjuangkan kepentingan rakyat. Kehadiran mereka sekadar untuk mengisi presensi. ${ }^{2}$

Partisipasi masyarakat diperlukan dalam rangka meminimalisir penyimpangan tujuan utama Undang-Undang. Oleh karena itu, dalam proses pembentukan Undang-Undang,

\footnotetext{
I Saldi Isra, Kekuasaan dan Perilaku Korupsi: Catatan Hukum (Jakarta: Penerbit Buku Kompas, 2009), 56.

2 Valina Singka Subekti, Dinamika Konsolidasi Demokrasi: Dari Ide Pembaruan Sistem Politik hingga ke Praktik Pemerintahan Demokratis (Jakarta: Yayasan Pustaka Obor Indonesia, 20 I 5), 94.
}

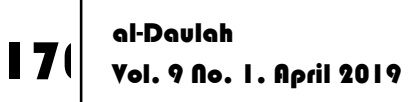


masyarakat seyogyanya selalu dilibatkan. Tidak semestinya masyarakat dianggap bodoh dan tidak mengetahui urusan publik. Berkembangnya berbagai sarana dan media informasi pada beberapa dasawarsa terakhir membuat pengetahuan begitu mudah diakses, tak terkecuali rakyat kecil. Fakta inilah yang meningkatkan daya kritis masyarakat terhadap apa yang terjadi.

Bukan hanya pada pembentukan Undang-Undang, pelaksanaan judicial review juga akan tersendat-sendat, jika tidak ada partisipasi dari masyarakat. Permohonan oleh seseorang atau kumpulan orang yang merasa bahwa haknya telah dirugikan merupakan sebuah kontrol bagi sebuah Undang-Undang, sebab sering kali sebuah Undang-Undang menguntungkan satu pihak. Akan tetapi, pihak lain merasa dirugikan. Jika hal itu terjadi, maka maksud dari pemberlakukan sebuah Undang-Undang belum terlaksana, bahkan terkesan membela kelompok elit yang dekat dengan penguasa.

Berdasarkan latar belakang di atas, penelitian ini bertujuan menggali sejauh mana hubungan antara partisipasi masyarakat, pembentukan Undang-Undang, dan judicial review.

\section{Pembahasan}

Kekuasaan yang kuat hanya bisa terwujud jika terdapat kebenaran di dalamnya. Sejalan dengan rasa keadilan yang ada dalam masyarakat, dan efektivitas kebenaran hanya bisa dirasakan dengan dukungan kekuasaan. Dialog menjadi salah satu cara yang cukup jitu untuk memadukan kekuasaan (might) dan kebenaran (right), dalam rangka mendorong terciptanya suasana kondusif. Hal ini dilakukan dengan praktek saling menghormati antara negara dan masyarakat. ${ }^{3}$

Negara boleh saja dibekali dengan seluruh perangkat pemaksa kekuasaan. Begitu pula sebaliknya, masyarakat boleh saja menyimpan aspirasi kebenaran. Akan tetapi, jika mereka tak mampu menerjemahkan aspirasi tersebut ke dalam mekanisme

3 Muhamad Hisyam (ed.), Krisis Masa Kini dan Orde Baru, (Jakarta: Yayasan Pustaka Obor Indonesia, 2003), 203. 
serta otoritas kekuasaan, maka yang akan muncul adalah kekacauan. Kekuasaan yang ingin bertahan harus menghargai aspirasi masyarakat dalam hal kebenaran. Di sisi lain, rekayasa politik bisa saja dilakukan oleh negara dengan maksud menunjukkan bahwa negaralah pengemban kebenaran sejati. ${ }^{4}$

Namun demikian, menurut Pabotinggi, dalam realitas kehidupan politik, kebenaran merupakan sesuatu yang dinamis, transparan, serta terbuka, sehingga tidak mungkin bisa dimonopoli. Ini berarti, kebenaran menuntut adanya partisipasi masyarakat yang pada saat ini mustahil dibatasi hanya dalam legalitas dan formalitas. Berdasarkan pandangan Alfian, hal ini dikarenakan munculnya kesadaran berpartisipasi akan menimbulkan diperkenankannya aktivitas mengemukakan pendapat, kehendak, serta keinginan politik. Jika taraf seperti itu terwujud, maka anggota masyarakat secara sadar ikut serta dalam memikirkan upaya pembangunan politik diarahkan dan dilaksanakan. ${ }^{5}$

Berdasarkan pandangan Soetandyo Wignjosoebroto, seiring dengan semakin maraknya ideologi demokrasi dan liberalisme yang memuncak pada penghujung abad ke-18, yang memposisikan rakyat dalam kesamaan derajat selaku pemegang kedaulatan tertinggi dalam pembuatan hukum nasional, hukum mulai tidak dikonsepsikan lagi sebagai norma moral yang berada di luar kuasa manusia. Alih-alih menjadi sesuatu yang internal, kodrati, serta hanya bisa dikatalisasi melalui kontemplasi kaum elit, sebagai bagian dari national order hukum mulai dirancang dan diteorikan menjadi norma yang lahir atas kuasa manusia-manusia sendiri. Bahkan, munculnya hukum sebagai norma bisa juga melalui kesepakatan orang awam yang menggelar musyawarah perwakilan. ${ }^{6}$

\footnotetext{
${ }^{4} \mathrm{lbid}$.

${ }^{5} \mathrm{lbid}$.

${ }^{6}$ Sudjito, IImu Hukum Holistik: Studi untuk Memahami Kompleksitas dan Pnegaturan Pengelolaan Irigasi (Yogyakarta: Gadjah Mada University Press, 20 I4), 39.
}

\section{7 ! $\mid \begin{aligned} & \text { al-Daulah } \\ & \text { Vol. } 9 \text { no. I. April } 2019\end{aligned}$}


Baik di Barat maupun Timur, demokrasi identik dengan ciri utamanya, yakni adanya partisipasi semua golongan masyarakat. Apabila demokrasi diartikan sebagai partisipasi anggota atau golongan yang ada dalarn masyarakat, maka hal ini sama saja dengan menerima pendirian bahwa demokrasi hanya mungkin diwujudkan ketika golongan masyarakat yang ada mempunyai kekuatan politik yang relatif seimbang. Jika salah satu golongan masyarakat terlalu kuat, maka kehidupan demokrasi menjadi terancam. Atau paling tidak, demokrasi tergantung pada kemauan penguasa. $^{7}$

Peran serta atau partisipasi masyarakat merupakan bagian dari prinsip demokrasi. Salah satu prasyarat utama dalam mewujudkan partisipasi itu adalah adanya keterbukaan atau transparansi. Asas keterbukaan (openness) mengandung sekurang-kurangnya 5 unsur utama yang memungkinkan peran serta masyarakat itu dapat terjadi, yakni: ${ }^{8}$

1. Hak untuk mengetahui (right to know, meewten). Hak ini pada dasarnya merupakan hak yang mendasar dalam alam demokrasi. Artinya, segala hal yang berkenaan dengan kepentingan publik, maka seyogyanya publik mengetahuinya secara utuh, benar dan akurat.

2. Hak untuk memikirkan (right to think, meedenken). Setelah masyarakat mendapat akses informasi tentang apa yang menjadi hak masyarakat untuk mengetahuinya, maka selanjutnya hak masyarakat pula untuk ikut serta terlibat dalam memberikan sumbangsih dalam rangka mendukung kebijakan pemerintah.

Philipus M. Hadjon mengemukakan bahwa konsep partisipasi masyarakat berkaitan dengan konsep keterbukaan. Dalam artian, tanpa keterbukaan pemerintahan tidak mungkin masyarakat dapat melakukan peran serta dalam kegiatan-kegiatan

\footnotetext{
7 Arief Budiman, Kebebasan, Negara, Pembangunan: Kumpulan Tulisan 1965-2005 (Jakarta: Pustaka Alvabet, 2006), 3.

8 YLBHI dan PSHK, Panduan Bantuan Hukum di Indonesia: Pedoman Anda Memahami dan Menyelesaikan Hukum, Cetakan kedua (Jakarta: YLBHI, 2007), 218.
} 
pemerintahan. Keterbukaan, baik "openheid"9 maupun "openbaarheid"10 sangat penting artinya bagi pelaksanaan pemerintahan yang baik dan demokratis. Dengan demikian, keterbukaan dipandang sebagai suatu asas ketatanegaraan mengenai pelaksanaan wewenang secara layak. ${ }^{11}$

Konsep partisipasi terkait dengan konsep demokrasi, sebagaimana dikemukakan oleh Philipus M. Hadjon, bahwa sekitar tahun 1960-an muncul suatu konsep demokrasi yang disebut demokrasi partisipasi. Dalam konsep ini, rakyat mempunyai hak untuk ikut memutuskan dalam proses pengambilan keputusan pemerintahan. Dalam konsep demokrasi, asas keterbukaan atau partisipasi merupakan salah satu syarat minimum, sebagaimana dikemukakan oleh Burkens dalam buku yang berjudul "Beginselen van de Democratische Rechstaat"bahwa: ${ }^{12}$

1. Pada dasarnya setiap orang mempunyai hak yang sama dalam pemilihan yang bebas dan rahasia

2. Pada dasarnya setiap orang mempunyai hak untuk dipilih

3. Setiap orang mempunyai hak-hak politik berupa hak atas kebebasan berpendapat dan berkumpul

4. Badan perwakilan rakyat mempengaruhi pengambilan keputusan melalui sarana (mede) beslissing-recht (hak untuk ikut memutuskan dan atau melalui wewenang pengawas

5. Asas keterbukaan dalam pengambilan keputusan dan sifat keputusan yang terbuka

6. Dihormatinya hak-hak kaum minoritas.

Asas keterbukaan sebagai salah satu syarat minimum dari demokrasi terungkap pula dalam pendapat Couwenberg dan Sri Soemantri Mertosoewignjo. Menurut S.W. Couwenberg lima asas demokratis yang melandasi rechtsstaat, dua di antaranya adalah asas

\footnotetext{
9 "Openheid" adalah suatu sikap mental berupa kesediaan untuk memberi informasi dan kesediaan untuk menerima pendapat pihak lain.

10 "Openbaar-heid" mempunyai arti: menunjukkan suatu keadaan.

" Ni Made Ari Yuliartini dan Anak Agung Sri Utari, "Partisipasi Masyarakat dalam Pembentukan Peraturan Daerah," Jurnal Kertha Patrika, Vol. 33 No. I, Januari 2008, 2.

12 lbid.
} 
pertanggungjawaban dan asas publik (openbaarheidsbeginsel), yang lainnya adalah: asas hak-hak politik, asas mayoritas, dan asas perwakilan. ${ }^{13}$ Senada dengan itu, Sri Soemantri M mengemukakan bahwa ide demokrasi menjelmakan dirinya dalam lima hal, dua diantaranya adalah: pemerintah harus bersikap terbuka (openbaarheid van bestuur) dan dimungkinkannya rakyat yang berkepentingan menyampaikan keluhannya mengenai tindakantindakan penjabat yang dianggap merugikan. ${ }^{14}$

Tampak jelas bahwa dalam paham demokrasi terdapat asas keterbukaan, yang berkaitan dengan asas partisipasi masyarakat, sebagaimana pula dikemukakan oleh Franz Magnis-Suseno bahwa paham demokrasi atau kedaulatan rakyat mengandung makna, pemerintahan negara tetap di bawah kontrol masyarakat. Kontrol ini melalui dua sarana: secara langsung melalui pemilihan para wakil rakyat dan secara tidak langsung melalui keterbukaan (publicity) pengambilan keputusan. Pertama, pemilihan wakil rakyat berkonsekuensi pada adanya pertanggungjawaban. Karena, jika partai-partai mau terpilih kembali dalam pemilihan berikut, mereka tidak dapat begitu saja mempermainkan kepercayaan para pendukung mereka, sehingga harus mempertanggungjawabkannya. Kedua, keterbukaan pengambilan keputusan merupakan suatu keharusan. ${ }^{15}$

Karena pemerintah bertindak demi dan atas nama seluruh masyarakat, maka seluruh masyarakat berhak untuk mengetahui apa yang dilakukannya. Bukan saja berhak mengetahui, juga berhak berpartisipasi dalam proses pengambilan keputusan.

Partisipasi masyarakat itu semakin terasa urgensinya dalam proses pengambilan keputusan setelah dikampanyekannya good

\footnotetext{
13 lbid.

${ }^{14} \mathrm{lbid}$.

15 lbid., 3.
} 
governance oleh Bank Dunia ${ }^{16}$ maupun UNDP ${ }^{17}$. Salah satu karakteristik dari good governance atau tata kelola pemerintahan yang baik atau kepemerintahan yang baik adalah partisipasi.

Selanjutnya UNDP mengartikan partisipasi sebagai karakteristik pelaksanaan good governance adalah keterlibatan masyarakat dalam pembuatan keputusan baik secara langsung maupun tidak langsung melalui lembaga perwakilan yang dapat menyalurkan aspirasinya. Partisipasi tersebut dibangun atas dasar kebebasan bersosialisasi dan berbicara serta berpartisipasi secara konstruktif. ${ }^{18}$

Senada dengan pengertian tersebut, Ann Seidman, Robert B. Seidman, dan Nalin Abeyserkere memaknai partisipasi sebagai berikut: bahwa pihak-pihak yang dipengaruhi oleh suatu keputusan yang ditetapkan the stakeholders (pihak yang mempunyai kepentingan) memiliki kesempatan yang seluas-luasnya untuk memberikan masukan, kritik dan mengambil bagian dalam pembuatan keputusan-keputusan pemerintahan. Pengertian partisipasi tersebut tidak jauh berbeda dengan pengertian partisipasi politik yang diberikan oleh Samuel P. Huntington dan Joan M. Nelson, yaitu bahwa partisipasi politik adalah kegiatan warga negara yang bertindak sebagai pribadi-pribadi, yang dimaksud untuk mempengaruhi pembuatan keputusan oleh pemerintah. ${ }^{19}$

Berdasarkan pendapat H.H.F.M Demen dan J.J.A. Thomassen, pengertian partisipasi politik sebagai kegiatan warga

\footnotetext{
${ }^{16}$ Bank Dunia adalah suatu badan peminjaman internasional yang menawarkan kredit kepada berbagai pemerintah, termasuk pemerintah negeri-negeri terbelakang, demi lancarnya proyekproyek pembangunan. Lihat Prisma, Vol. 6. 1977. Jakarta: Lembaga Penelitian, Pendidikan \& Penerangan Ekonomi dan Sosial (LP3ES), 60.

${ }_{17}$ United Nations Development Programme (UNDP) adalah salah satu organisasi internasional yang gencar menyebarluaskan urgensi konsep human security atau keamanan insani dalam rangka mengimbangi konsep national security yang terlalu menekankan perlindungan terhadap negara berdaulat. Lihat Aleksius Jemadu, Politik Global dalam Teori \& Praktik (Yogyakarta: Graha Ilmu, 2008), 142.

${ }^{18} \mathrm{Ni}$ Made Ari Yuliartini dan Anak Agung Sri Utari, "Partisipasi Masyarakat..., 3.

19 lbid.
} 
negara terlibat dalam proses pengambilan keputusan, dalam kepustakaan kebijakan publik di Belanda disebut inspraak atau partisipasi politik langsung ${ }^{20}$. Menurut Miriam Budiardjo, ciri terpenting dari partisipasi politik langsung adalah tidak melalui proses perwakilan, melainkan warga negara berhubungan langsung denganpara pengambil keputusan. Dikaitkan dengan pendapat Herbert Mc Closky, bahwa partisipasi politik adalah kegiatan-kegiatan sukarela dari warga masyarakat melalui mana mereka mengambil bagian dalam proses pemilihan penguasa, dan secara langsung atau tidak langsung, dalam proses pembentukan kebijakan publik.21 Sehingga jelas, partisipasi politik langsung merupakan salah satu bentuk partisipasi politik dan bentuk lainnya dapat disebut sebagai partisipasi politik tidak langsung.

Dalam partisipasi politik terdapat sasaran yang ingin dituju, yaitu proses pembuatan keputusan politik. Dengan demikian, partisipan memiliki tujuan untuk mempengaruhi keputusan politik yang akan diambil, supaya keputusan tersebut menguntungkannya atau sekurangnya tidak rnerugikannya. ${ }^{22}$

\section{Partisipasi Masyarakat dalam Pembentukan Undang-Undang}

Partisipasi masyarakat dalam pembentukan UndangUndang pada saat ini sudah mulai dikembangkan. Hal tersebut terlihat dengan mulai dilakukannya Rapat Dengar Pendapat Umum, atau rapat-rapat lainnya, kunjungan kerja, ataupun pelaksanaan seminar-seminar atau kegiatan yang sejenis, untuk mendapatkan masukan dari masyarakat.

Dalam hal pelaksanaan partisipasi masyarakat, Muhammad A.S. Hikam, Ketua Badan Legislasi (Baleg) Dewan Perwakilan Rakyat, periode tahun 2004-2005, menyatakan bahwa:

\footnotetext{
$20 \mathrm{lbid}$.

21 Ibid. Menurut Sahdan, partisipasi politik masyarakat dinilai sebagai elemen utama dalam pengambilan kebijakan publik. Respek negara terhadap kedaulatan rakyat dinilai dari sejauh mana negara membuka sejumlah ruang bagi partisipasi masyarakat dalam lembaga-lembaga politik. Adi Sasono, Rakyat Bangkit Bangun Martabat, (Tangerang: Pustaka Alvabet dan Dewan Koperasi Indonesia [Dekopin], 2008), 152.

22 Budi Susanto, S.J. (ed)., Politik \& Postkolonialitas di Indonesia (Yogyakarta: Kanisius, 2003), 198.
} 
"Partisipasi masyarakat dalam rangka pembentukan Undang-Undang sudah mulai terbangun. Awalnya partisipasi masyarakat dimulai dengan pemberian masukan kepada DPR, baik melalui komisi atau Badan Legislasi (Baleg), mulai dari penyusunan program legislasi, penyiapan Rancangan Undang-Undang, dan dalam pembahasan suatu Rancangan Undang-Undang. Partisipasi itu kemudian meningkat dengan memberikan masukan kepada fraksi-fraksi atau langsung kepada anggota DPR. Peningkatan partisipasi juga terlihat dengan seringnya diadakan seminar-seminar atau kegiatan semacamnya yang berkaitan dengan isu-isu yang berkaitan dengan Rancangan Undang-Undang." 23

Walaupun pengaturan tentang partisipasi masyarakat telah dicanangkan, namun demikian jangan sampai hal itu dipakai alat oleh para pembentuk peraturan perundang-undangan untuk duduk dan berpangku tangan, sambil menunggu masukan rancangan peraturan perundang-undangan yang berasal dari masyarakat. Apabila terjadi bahwa masyarakat berlomba-lomba memberikan berbagai rancangan peraturan perundang-undangan, maka seyogyanya para pembentuk peraturan perundangundangan juga melakukan pengkajian dan penelitian kembali, apakah rancangan peraturan perundang-undangan tersebut memang diperlukan atau tidak. Dengan cara seperti itu, dapat diharapkan terbentuknya peraturan perundang-undangan yang baik, dan dapat menampung aspirasi masyarakat, sehingga penerapannya tidak menimbulkan keresahan dan kekacauan dalam masyarakat.

Partisipasi masyarakat dalam pembentukan UndangUndang saat ini telah dirasakan mulai mendapat sambutan dari berbagai kalangan, seperti Dewan Perwakilan Rakyat, Dewan Perwakilan Daerah, Kementerian Negara atau Lembaga pemerintah

${ }^{23}$ Maria Farida Indrati S., Ilmu Perundang-undangan 2, (Yogyakarta: Kanisius, 2007), 262. 
non Departemen, bahkan perguruan tinggi dan lembaga swadaya masyarakat yang mempunyai perhatian dalam pembentukan perundang-undangan. Hal tersebut dapat dilihat dari terselenggaranya berbagai seminar, diskusi, atau pertemuanpertemuan lainnya dalam rangka melakukan pengkajian atau menindaklanjuti berbagai penelitian untuk menyiapkan suatu rancangan Undang-Undang. Dengan adanya kesungguhan dari berbagai kelompok tersebut dalam menyiapkan suatu rancangan Undang-Undang, diharapkan pembentukan peraturan perundangundangan di masa yang akan datang dapat lebih baik daripada saat ini. ${ }^{24}$

Partisipasi masyarakat luas adalah salah satu faktor yang mengurangi kemungkinan adanya kepentingan-kepentingan lembaga dan kelompok yang mencemari Undang-Undang. Partisipasi masyarakat memastikan bahwa Undang-Undang yang dihasilkan tidak disusun draftnya hanya oleh sebuah elite politik. Sebuah parlemen pembuat konstitusi punya peluang yang lebih baik untuk mendapatkan legitimasi hulu yang kuat ketimbang sebuah komisi ahli. Tetapi, parlemen demikian rentan sifatnya, karena bisa saja direcoki oleh kepentingan partai-partai politik dan kepentingan parlemen itu sendiri.

Partisipasi masyarakat sangatlah penting dalam membuat sebuah konstitusi yang demokratis, karena mampu memperkuat rasa memiliki di pihak rakyat terhadap Undang-Undang yang bersangkutan. Konsultasi publik haruslah memenuhi sedikitnya dua aturan dasar: kontribusi yang aktif dan inklusif. Agar menjadi kontribusi yang aktif, konsultasi publik harus dimulai sebelum aspek-aspek Undang-Undang yang baru ditetapkan secara efektif. Kegiatan konsultasi atau musyawarah harus beranjak lebih dari sekadar mendidik public yang pasif dan harus melakukan segala usaha untuk bisa secara aktif melibatkan masyarakat dalam proses pembuatan Undang-Undang. Kegiatan partisipasi harus interaktif dan memberdayakan, mendorong masyarakat untuk memberikan

24 Ibid. 
kontribusi yang kontruktif bagi proses tersebut. Jadi, tindak lanjut adalah sesuatu yang krusial untuk menunjukkan kepada masyarakat bahwa urun rembuk dari mereka dipertimbangkan dengan serius.

Kemudian, untuk bisa menumbuhkan partisipasi publik yang inklusif, diperlukan strategi untuk mengatasi dominasi kelompok tertentu dan unuk merangsang partisipasi dari kelompok lain yang mungkin masih bungkam. Sayangnya, isu-isu UndangUndang yang penting justru jarang diminati masyarakat luas. ${ }^{25}$

Beberapa hal yang dapat dilakukan dalam kaitannya dengan pelaksanaan peran serta masyarakat dalam pembentukan UndangUndang antara lain: dilakukannya Rapat Dengar Pendapat Umum atau rapat-rapat lainnya yang bertujuan menyerap aspirasi masyarakat, dilakukannya kunjungan oleh anggota DPR untuk mendapat masukan dari masyarakat, ataupun diadakannya seminar-seminar atau kegiatan yang sejenis dalam rangka melakukan pengkajian atau menindak lanjuti berbagai penelitian untuk menyiapkan suatu Rancangan Undang-Undang. Akan tetapi dalam pelaksanaannya, terkadang masih terdapat berbagai penafsiran tentang siapa yang dimaksud dengan istilah masyarakat, ada yang mengartikan setiap orang pada umumnya, setiap orang atau lembaga yang terkait, atau setiap lembaga swadaya masyarakat.

Maria Farida Indrati S berpendapat bahwa yang dimaksud dengan masyarakat adalah setiap orang pada umumnya terutama masyarakat yang "rentan" terhadap peraturan tersebut, setiap orang atau lembaga terkait, atau setiap lembaga swadaya masyarakat yang terkait. Mengenai sejauh mana masyarakat tersebut dapat ikut serta dalam pembentukan peraturan UndangUndang, hal tersebut dapat tergantung pada keadaan dari pembentuk perundang-undangan sendiri oleh karena UUD dan berbagai peraturan perundang-undangan telah menetapkan

\footnotetext{
${ }^{25}$ Denny Indrayana, Indonesian Constitutional Reform 1999-2002, terj. E. Setiyawati A, (Bandung: PT. Mizan Pustaka, 2007), I I I.
}

\section{I81 $\begin{aligned} & \text { al-Daulah } \\ & \text { Vol. } 9 \text { no. I. April } 2019\end{aligned}$}


lembaga mana yang dapat membentuk peraturan perundangundangan tersebut. Apabila suatu Undang-Undang telah dapat menampung aspirasi masyarakat luas tentunya peran serta masyarakat tersebut tidak akan terlalu dipaksakan pelaksanaannya. Oleh karena itu diperlukan peningkatan kualitas anggota DPRD maupun seluruh jajaran Pemerintah yang mempunyai tugas membentuk suatu Undang-Undang. ${ }^{26}$

\section{Kedudukan Masyarakat dalam Judicial Review}

Judicial review tidak lain merupakan upaya untuk melakukan review, penilaian kembali, peninjauan kembali, atau pengujian kembali atas norma hukum yang tertib, baik dalam bentuk produk pengaturan (regeling), penetapan (beschikking), atau pun produk pengadilan (vonnis). Judicial review merupakan mekanisme untuk pengendalian dan kontrol norma hukum oleh lembaga peradilan (norms control mechanism). Karena itu, di Inggris, pemeriksaan atas produk-produk administratif (beschikking) oleh peradilan tata usaha juga disebut dengan perkataan judicial review juga. Demikian pula di Amerika Serikat, upaya hukum Peninjauan Kembali (PK) juga disebut dengan judicial review. Dalam pengertian yang lebih lebih teknis di Indonesia, yang dimaksud dengan perkataan judicial review itu tidak lain merupakan upaya hukum untuk menilai atau tindakan pengadilan untuk menguji peraturan perundangundangan, baik dari segi materi atau pun pembentukannya. ${ }^{27}$

Bagaimanapun, diperlukan pelembagaan judicial review atau hak uji material oleh suatu lembaga negara atas undang-undang dan peraturan perundang-undangan yang berada dalam tingkatan di bawahnya. Urgensi pelembagaan judicial review semakin relevan ketika disadari melimpahnya peraturan yang saling berbenturan baik secara vertikal maupun horisntal. Judicial review berfungsi mengawal setiap produk peraturan perundang-undangan agar senantiasa konsisren dengan peraturan di atasnya. Pelembagaan judicial review dilakukan dalam rangka menjamin konsistensi

\footnotetext{
${ }^{26}$ Ni Made Ari Yuliartini dan Anak Agung Sri Utari, "Partisipasi Masyarakat..., 4.

27 Jimly Asshiddiqie, Konstitusi Ekonomi, (Jakarta: Penerbit Buku Kompas, 20 I 0), 43.
} 
peraturan perundang-undangan dengan peraturan dasarnya, atau membangun tata hukum sesuai apa yang digariskan dalam Pancasila sebagai dasar ideologi, cita hukum, serta staats fundamentalnorm..$^{28}$

Kedudukan masyarakat dalam mengajukan permohonan judicial review-baik ke MA maupun ke MK-sangatlah urgen. Untuk dapat mengajukan permohan judicial review ke MA ataupun MK, seseorang harus memenuhi terlebih dahulu legal standing suatu subjek hukum atau kedudukan hukum seseorang. Legal standing pemohon telah ditentukan dalam Pasal 51 ayat (1) UU MK bahwa pemohon adalah pihak yang menganggap hak dan/atau kewenangan konstitusionalnya ${ }^{29}$ dirugikan oleh berlakunya Undang-Undang. Berikut pihak yang dapat mengajukan permohonan judicial review ke Mahkamah Konstitusi: ${ }^{30}$

1. Perorangan warga negara Indonesia

2. Kesatuan masyarakat hukum adat, sepanjang masih hidup dan sesuai dengan perkembangan masyarakat dan prinsip Negara Kesatuan Republik Indonesia yang diatur dalam Undang-Undang.

3. Badan hukum publik atau privat

4. Lembaga negara.

Sedangkan pengajuan judicial review ke Mahkamah Agung hanya dapat dilakukan oleh pihak yang menganggap haknya dirugikan oleh berlakunya peraturan perundang-undangan di bawah undang-undang, yaitu:

1. Perorangan warga negara Indonesia;

2. Kesatuan masyarakat hukum adat sepanjang masih hidup dan sesuai dengan perkembangan masyarakat dan prinsip Negara Kesatuan Republik Indonesia yang diatur dalam undang-undang; atau

\footnotetext{
28 M. Nasruddin Anshoriy Ch., Dekonstruksi Kekuasaan: Konsolidasi Semangat Kebangsaan, (Yogyakarta: LKiS, 2008), 187.

29 Hak konstitusional adalah hak-hak yang diatur dalam UUD 1945. Adapun yang dimaksud dengan perorangan termasuk kelompok orang yang mempunyai kepentingan sama.

${ }^{30}$ Rocky Marbun, Kiat Jitu Menyelesaikan Kasus Hukum, (Jakarta: Visimedia, 20I I), 292.
} 
3. Badan hukum publik atau privat. ${ }^{31}$

Dari kutipan-kutipan di atas dapat diketahui bahwa setiap pemohon haruslah memahami kondisi berikut:

1. Pemohon adalah salah satu dari keempat kelompok subjek hukum tersebut di atas

2. Bahwa subjek hukum yang dimaksud memang mempunyai hak-hak atau kewenangan-kewenangan sebagaimana diatud dalam UUD 1945

3. Bahwa hak atau kewenangan konstitusional yang bersangkutan memang telah dirugikan atau dilanggar oleh berlakunya Undang-Undang atau bagian dari UndangUndang yang dipersoalkannya itu

4. Bahwa adanya atau timbulnya kerugian dimaksud memang terbukti mempunyai hubungan sebab akibat atau hubungan kausal (causal verband) dengan berlakunya Undang-Undang yang dimaksud.

5. Bahwa apabila permohonan yang bersangkutan kelak dikabulkan, kerugian konstitusional yang bersangkutan memang dapat dipulihkan kembali dengan dibatalkannnya Undang-Undang dimaksud.

Jika kelima kriteria ini tidak dapat dipenuhi secara kumulatif, yang bersangkutan dapat dipastikan memiliki legal standing untuk mengajukan permohonan perkara ke Mahkamah Konstitusi.

\section{Hubungan antara Partisipasi Masyarakat, Pembentukan Undang- Undang dan Judicial Review}

Penjelasan di atas menunjukan bahwa dalam pembentukan Undang-Undang dan pelaksanaan judicial review, terdapat hak masyarakat untuk berpartisipasi di dalamnya. Masyarakat bisa memberi masukan secara lisan atau tertulis dalam persiapan

\footnotetext{
31 Lihat Pasal 3 IA ayat (2) Undang-Undang No. 3 Tahun 2009 tentang Mahkamah Agung. Bandingkan dengan Undang-Undang No. 24 Tahun 2003 tentang Mahkamah Konstitusi Pasal 5 I ayat (I) di atas, yang mencakup lembaga negara sebagai pihak yang bisa mengajukan judicial review ke Mahkamah Konstitusi. Dalam Undang-Undang No. 8 Tahun 20II Tentang Perubahan atas Undang-Undang No. 24 Tahun 2003 Tentang Mahkamah Konstitusi, hal tersebut tidak mengalami perubahan.
} 
maupun pembahasan pembentukan Undang-Undang. Sedangkan dalam judicial review, masyarakat bisa turut serta sebagai pihak yang mengkontrol apakah sebuah Undang-Undang sudah sesuai dengan Undang-Undang dengan Undang-Undang lainnya yang lebih tinggi (yang berada dalam kewenangan MA), atau Undang-Undang dengan Undang-Undang Dasar (yang merupakan yurisdriksi MK) atau belum.

Partisipasi sebagai wujud keterlibatan masyarakat, baik dalam pembentukan undang-undang maupun dalam pelaksanaan judicial review, berperan besar dalam upaya pembangunan hukum sekaligus pembaruan tatanan hukum di Indonesia. Digencarkannya partisipasi masyarakat di ruang publik bertujuan supaya hukum dapat meningkatkan peran dan fungsinya sebagai referensi atau rujukan berperilaku dalam kehidupan bersama. Dengan demikian, anggapan bahwa hukum merupakan medium penyokong kepentingan individu bisa diluruskan.

Menurut Sad Dian Utomo, manfaat partisipasi masyarakat dalam pembuatan kebijakan publik, - termasuk di sini dalam pembuatan Undang-Undang dan pelaksanaan judicial reviewadalah: $^{32}$

1. Memberikan landasan yang lebih baik untuk pembuatan kebijakan publik.

2. Memastikan adanya implementasi yang lebih efektif karena warga mengetahui dan terlibat dalam pembuatan kebijakan publik.

3. Meningkatkan kepercayaan warga kepada eksekutif dan legislatif.

4. Efisiensi sumber daya, sebab dengan keterlibatan masyarakat dalam pembuatan kebijakan publik dan mengetahui kebijakan publik, maka sumber daya yang digunakan dalam sosialisasi kebijakan publik dapat dihemat.

\footnotetext{
32 Ni Made Ari Yuliartini dan Anak Agung Sri Utari, "Partisipasi Masyarakat..., 3.
} 
Sesuai dengan ide negara hukum, maka partisipasi masyarakat dalam penyusunan Undang-Undang mesti diatur secara jelas dalam suatu aturan hukum tertentu. Peraturan perundang-undangan memberikan legitimasi bagi terpeliharannya partisipasi masyarakat, terutama dalam kehidupan bernegara. Dengan potensi dan gagasan yang dimiliki, mereka diberi kesempatan yang besar untuk turut menentukan nasib negaranya.

Mulyana W. Kusuma menekankan bahwa keikutsertaan masyarakat dalam pembuatan hukum diharapkan menjadi kekuatan kontrol (agent of sosial control) sekaligus kekuatan penyeimbang antara kepentingan pemerintah dan masyarakat. Pada situasi ditemukannya hukum responsif, peluang untuk berpartisipasi dalam pembentukan hukum lebih terbuka. Dengan demikian, arena hukum menjadi semacam forum politik, sedangkan partisipasi hukum memuat dimensi politik. Ini berarti, aksi hukum merupakan wahana bagi kelompok atau organisasi dalam rangka berperan serta menentukan kebijaksanaan umum. ${ }^{33}$

Lothar Gundling mengemukakan bahwa manfaat yang bisa diambil dari partisipasi adalah informing the administration, increasing the readiness the public to accept decisions, dan supplementing judicial protection. Selain itu, partisipasi masyarakat juga memiliki arti penting sebagai upaya democratizing decision-making. Dengan makna inilah, peraturan perundang-undangan bisa mempunyai kelebihan dalam efektivitas pemberlakuannya dalam masyarakat. Partisipasi juga memberikan legitimasi atau dukungan politik rnasyarakat terhadap pembentukan peraturan perundangundangan. ${ }^{34}$

Bentuk-bentuk implementasi partisipasi masyarakat tergantung pada keadaan masarakat dan lingkungannya. Kepedulian lembaga pendidikan atau lembaga swadava masyarakat, tingkat sumberdava masyarakat, serta sikap pemerintah berpengaruh terhadap pola-pola partisipasi yang

33 Dayanto, Peraturan Daerah Responsif: Fondasi Teoretik dan Pedoman Pembentukannya, (Yogyakarta: Deepublish, 20I5), I57-I58.

${ }^{34}$ Ibid., 158. 
ditunjukkan oleh masyarakat dalam menvalurkan aspirasi. ${ }^{35}$ Melalui Undang-Undang Republik Indonesia Nomor 12 Tahun 2011 Tentang Pembentukan Peraturan Perundang-Undangan, ruang partisipasi masyarakat dalam pembentukan peraturan perundangundangan semakin terbuka lebar. Pasal 96 undang-undang ini mengatur tentang partisipasi masyarakat:

“(1) Masyarakat berhak memberikan masukan secara lisan dan/atau tertulis dalam pembentukan Peraturan Perundang-undangan. (2) Masukan secara lisan dan/atau tertulis sebagaimana dimaksud pada ayat (1) dapat dilakukan melalui: a. rapat dengar pendapat umum; $b$. kunjungan kerja; c. sosialisasi; dan/atau d. seminar, lokakarya, dan/atau diskusi. Dalam sejarah perundangundangan, partisipasi masyarakat juga pernah diatur dalam UU No. 10 tahun 2004 tentang Pembentukan Peraturan Perundang-Undangan, yaitu pada Bab X pasal 53 yang menyatakan bahwa masyarakat berhak memberikan masukan secara lisan atau tertulis dalam rangka penyiapan atau pembahasan rancangan undangundang dan rancangan peraturan daerah."

Sendi utama negara hukum, menurut Bagir Manan adalah hukum merupakan sumber tertinggi (supremasi hukum) dalam mengatur dan menentukan mekanisme hubungan hukum antara negara dan masyarakat atau antar-anggota masyarakat yang satu dengan yang lainnya. Hukum mempunyai dua pengertian, yakni hukum tertulis dan hukum tidak tertulis. Bapak Pembentuk Negara Indonesia, mengakui adanya hukum tidak tertulis, sebagaimana pernah dituangkan dalam Pembukaan UUD 1945: "UndangUndang Dasar ialah hukum dasar yang tertulis, sedang di sampingnya Undang-Undang Dasar itu berlaku juga hukum dasar yang tidak tertulis, ialah aturan-aturan dasar yang timbul dan

35 lbid.

$181 \mid \begin{aligned} & \text { al-Daulah } \\ & \text { Vol. } 9 \text { ก०. I. April } 2019\end{aligned}$ 
terpelihara dalam praktek penyelenggaraan negara meskipun tidak tertulis". ${ }^{36}$

Berkenaan dengan negara hukum, Moh. Kusnardi dan Bintan R. Saragih mengemukakan, bahwa legalitas dalam arti hukum dalam segala bentuknya sebagai ciri negara hukum adalah setiap tindakan baik dari pihak penguasa maupun dari pihak rakyat harus dibenarkan secara hukum. ${ }^{37}$ Mengenai asas legalitas, Jimly Asshiddiqie berpendapat, bahwa dalam setiap Negara Hukum diisyaratkan berlakunya asas legalitas dalam segala bentuknya (due process of law), yaitu bahwa segala tindakan pemerintahan harus didasarkan atas peraturan perundang-undangan yang sah dan tertulis. ${ }^{38}$

Dari pendapat-pendapat tersebut, dapat dikatakan bahwa setiap tindakan penyelenggara negara maupun warga negara harus berdasarkan aturan hukum, baik aturan hukum yang tertulis maupun yang aturan hukum yang tidak tertulis. Yang dimaksud aturan hukum tertulis di sini adalah peraturan perundangundangan, sedangkan yang dimaksud dengan aturan hukum yang tidak tertulis di sini adalah dalam bidang pembentukan peraturan perundang-undangan, yakni asas-asas pembentukan peraturan perundang-undangan yang baik, yang kemudian dituangkan dalam UU Nomor 12 Tahun 2011. ${ }^{39}$

Dengan demikian, partisipasi masyarakat dalam pembentukan Undang-Undang tidak saja cukup diatur dalam peraturan perundang-undangan, namun apa yang telah digariskan dalam produk legislasi harus bisa diimplementasikan. Sehingga, ketetapan dalam peraturan perundang-undangan bukan hanya sebagai wacana teoritis, namun diwujudkan dalam tataran praktis. Hal ini juga dalam rangka menyeimbangkan antara law in book dan law in action. Hubungan antara partisipasi masyarakat,

\footnotetext{
${ }^{36} \mathrm{Ni}$ Made Ari Yuliartini dan Anak Agung Sri Utari, "Partisipasi Masyarakat..., 4.

${ }^{37}$ lbid.

38 lbid.

39 Yang dimaksud asas di sini yaitu: a. kejelasan tujuan; b. kelembagaan atau pejabat pembentuk yang tepat; c. kesesuaian antara jenis, hierarki, dan materi muatan; d. dapat dilaksanakan; e. kedayagunaan dan kehasilgunaan; f. kejelasan rumusan; dan g. keterbukaan.
} 
pembentukan Undang-Undang, dan judicial review sangat erat, di mana ketiganya saling terkait satu sama lain. Baik pembentukan Undang-Undang maupun dilaksanakannya judicial review memerlukan partisipasi masyarakat sebagai warga negara. Keaktifan mereka dalam setiap hal yang menyangkut hajat hidup bersama merupakan di antara faktor berjalannya fungsi negara. Lebih dari itu, partisipasi menjadi salah satu pilar terbentuknya good governance.

Yang tak kalah penting yaitu keterlibatan atau keikutsertaan masyarakat dalam pembentukan Undang-Undang dan judicial review menunjukkan bahwa mereka cukup kritis. Perhatian mereka terhadap urusan publik menggambarkan bahwa mereka genap memiliki daya berpikir yang tinggi. Di sela-sela mengejar kebutuhan hidup, masyarakat masih menyempatkan diri untuk memperhatikan peran peraturan perundang-undangan. Mereka mempertanyakan apakah fungsi produk legsilasi sudah berjalan sebagaimana mestinya atau belum. Undang-Undang yang lahir tanpa keterlibatan masyarakat di dalamnya terancam kurang aplikatif atau bahkan dikhawatirkan gagal. Tanpa menyerap aspirasi masyarakat, produk legislasi akhirnya bercorak elitis, karena hanya mencerminkan kepentingan golongan tertentu. Undang-Undang hanya menjadi domain suatu kalangan yang dekat dengan kekuasaan.

Apa yang terlanjur digariskan di dalamnya lahir atas hasrat para elite dan jauh dari kepentingan kalangan akar rumput. Ketika diterapkan, manfaatnya kurang dapat dirasakan oleh publik atau bahkan tidak berimbas sama sekali. Jika ini yang terjadi, maka pembuat Undang-Undang telah mengalami kegagalan dalam menjalankan peran dan fungsinya. Akhirnya, setelah diterbitkan Undang-Undang hanya memenuhi lemari para akademisi dan praktisi hukum lantaran kurang mampu menjawab problematika masyarakat.

Negara hukum menggariskan hak yang sama bagi semua warga negara. Bagaimanapun, mereka berhak diperlakukan secara 
adil di hadapan hukum. Dengan lahirnya lembaga yang secara khusus menangani judicial review, segenap masyarakat berhak menilai seberapa jauh hukum mampu menjamin hak-hak konstitusionalnya. Ini merupakan lompatan besar karena warga negara memiliki wahana untuk mengoreksi apakah hukum benarbenar telah menjamin hak-haknya atau belum. ${ }^{40}$ Lahirnya UndangUndang dan pengajuan uji material atas peraturan perundangundangan di bawah Undang-Undang (wewenang MA) dan Undang-Undang terhadap Undang-Undang Dasar (wewenang MK) menuntut adanya partisipasi. Sehingga, diterbitkannya produk legislasi menyimpan jiwa kebersamaan di dalamnya. Masyarakat tidak hanya dituntut untuk mengawal lahirnya Undang-Undang, namun juga memantau seberapa besar pengaruhnya bagi kehidupan.

Ini berarti, keterlibatan masyarakat harus ada dari hulu sampai hilir. Dalam konteks ini, hulu berarti proses lahirnya produk legislasi. Adapun hilir mengisyaratkan proses evaluasi terhadap produk legislasi. Partisipasi tidak mungkin dilakukan hanya pada salah satunya, baik pada hulu ataupun hilirnya. Dengan demikian, rasanya belum lengkap apabila masyarakat hanya berpartisipasi pada waktu proses munculnya Undang-Undang, adapun setelah diterbitkan, mereka tidak terlibat dalam upaya mengawasi UndangUndang tersebut. Begitu pula sebaliknya. Rasanya kurang lengkap jika masyarakat hanya berkontribusi dalam upaya pengawasan jalannya produk legislasi tanpa mau terlibat pada saat UndangUndang dilahirkan.

Partisipasi juga berarti pendewasaan terhadap proses berpikir masyarakat. Berbeda dengan negara otoriter yang terlalu melampaui urusan rakyat, negara demokrasi menghendaki bahwa rakyat mempunyai andil dalam kehidupan bermasyarakat, berbangsa, dan bernegara. Adanya negara bercorak demokratis tidak hanya ditandai dengan keaktifan para pejabat negara dalam

${ }^{40}$ Andi Mappetahang Fatwa, Potret Konstitusi Pasca Amandemen UUD 1945, (Jakarta: Penerbit Buku Kompas, 2009), 23-24. 
menjalankan tugasnya, melainkan juga keikutsertaan masyarakat dalam urusan publik.

Apalagi, dalam pandangan Sudjito, pengalaman sejarah dalam membangun bangsa dan negara genap menumbuhkan kecerdasan dan kreativitas baru dalam memilih sekaligus menentukan konsep perubahan yang dipandang sesuai, efektif, serta manjur dalam konteks zamannya. ${ }^{41}$

Terbukanya keran demokrasi terutama pasca reformasi selalu membuka kemungkinan bagi pemerintah untuk memberikan penghargaan terhadap keberadaan rakyat. Hal ini bukan diwujudkan dengan upaya untuk selalu memenuhi kebutuhan mereka sebagaimana ditempuh oleh Orde Baru, melainkan dengan mengajak mereka untuk "berpikir bersama". Bukan berarti pemerintah membebani rakyat untuk memeras otaknya, akan tetapi lebih pada usaha menghormati hak mereka sebagai warga negara.

Adanya partisipasi masyarakat, khususnya dalam mengawal lahir dan berjalannya produk legislasi, menandakan bahwa terbangunnya good governance tidak berpola top-down, melainkan bottom-up. Kokohnya kekuasaan ditopang oleh sumbangsih pemikiran mereka supaya negara beserta aparaturnya senantiasa berjalan sesuai koridor. Bagaimanapun, pemerintahan yang baik menghendaki adanya kontribusi dan peran serta warga negara dalam memenuhi kepentingan bersama.

\section{Penutup}

Dari uraian di atas dapat ditarik beberapa kesimpulan sebagai berikut: pertama, partisipasi masyarakat dalam pembentukan Undang-Undang dan pelaksanaan judicial review dapat: (a) Memberikan landasan yang lebih baik untuk pembuatan kebijakan publik dalam menciptakan suatu good governance. (b) Meningkatkan kepercayaan warga kepada eksekutif dan legislatif. (c) Efisiensi sumber daya manusia, sebab dengan keterlibatan

${ }^{41}$ Sudjito Atmoredjo, Ideologi Hukum Indonesia, (Yogyakarta: Lingkar Media, 20 I6), 199. 
masyarakat dalam pembuatan kebijakan publik, maka sumber daya yang digunakan dalam sosialisasi kebijakan publik dapat diminimalisir.

Kedua, partisipasi masyarakat dalam mengevaluasi UndangUndang menjadi satu kegiatan penting, demi mengadakan kontrol apakah sebuah Undang-Undang sudah sesuai dengan tujuannya atau belum. Masyarakat dapat mengajukan judicial review kepada MA atau MK apabila merasa haknya dirugikan oleh UndangUndang tertentu. Ketiga, hubungan antara partisipasi masyarakat dengan pembuatan Undang-Undang dan pelaksanaan judicial review sangatlah erat. Ini mengingat bahwa tanpa partisipasi masyarakat, Undang-Undang yang dihasilkan kurang mencerminkan kepentingan masyarakat dan hanya mengutamakan kepentingan segelintir orang. Adapun MK dan MA tidak akan melakukan judicial review jika tidak ada permintaan dari masyarakat.

Adapun saran dan rekomendasi yang diajukan yaitu: pertama, upaya melibatkan masyarakat dalam membentuk UndangUndang dapat dilakukan dengan dua cara, yaitu partisipasi aktif dan partisipasi pasif. Melalui partisipasi aktif, masyarakat berinisiatif untuk berperan serta dalam proses pembentukan produk legislasi dengan cara mengikuti rapat umum dan debat publik, serta menulis surat terbuka di media massa yang ditujukan kepada alat kelengkapan yang bertugas membahas Rancangan Undang-Undang (RUU). Adapun partisifasi pasif mengandung arti bahwa inisiatif partisipasi berasal dari luar masyarakat. Dalam hal ini, lembaga legislatif atau eksekutif bisa menggelar dialog publik, rapat dengar pendapat (hearing), sosialisasi, kunjungan kerja, seminar, serta lokakarya. Namun demikian, yang perlu diperhatikan yaitu partisipasi terakhir ini harus bersifat substansial, bukan sekadar formalitas dan prosedural.

Kedua, partisipasi masyarakat dalam optimalisasi UndangUndang melalui judicial review kerap terhambat oleh masalah teknis, antara lain keterbatasan hakim dan sulitnya mengumpulkan hakim dalam satu waktu. Sebagaimana diketahui, undangan dari berbagai 
institusi dan digelarnya studi banding ke luar negeri membuat proses penanganan perkara menjadi lebih lama. Atas dasar itulah, para hakim baik MA maupun MK dituntut selektif. Mereka semestinya memiliki skala prioritas, sehingga mampu menilai mana yang lebih didahulukan. Ketika agenda-agenda di luar dinilai kurang esensial, maka permohonan Judicial Review harus segera ditangani supaya tidak menumpuk di kemudian hari yang akhirnya menjadi beban psikologis.

\section{Daftar Pustaka}

Anshoriy Ch, M. Nasruddin. Dekonstruksi Kekuasaan: Konsolidasi Semangat Kebangsaan. Yogyakarta: LKiS, 2008.

Armando, Ade. Televisi Jakarta di Atas Indonesia. Yogyakarta: Bentang, 2011.

Asshiddiqie, Jimly. Konstitusi Ekonomi. Jakarta: Penerbit Buku Kompas, 2010.

Atmoredjo, Sudjito. Ideologi Hukum Indonesia. Yogyakarta: Lingkar Media, 2016.

Budiman, Arief. Kebebasan, Negara, Pembangunan: Kumpulan Tulisan 1965-2005. Jakarta: Pustaka Alvabet, 2006.

Dayanto. Peraturan Daerah Responsif: Fondasi Teoretik dan Pedoman Pembentukannya. Yogyakarta: Deepublish, 2015.

Fatwa, Andi Mappetahang. Potret Konstitusi Pasca Amandemen UUD 1945. Jakarta: Penerbit Buku Kompas, 2009.

Hisyam, Muhamad (ed.). Krisis Masa Kini dan Orde Baru. Jakarta: Yayasan Pustaka Obor Indonesia, 2003.

Indrati S, Maria Farida. Ilmu Perundang-undangan 2. Yogyakarta: Kanisius, 2007.

Indrayana, Denny. Indonesian Constitutional Reform 1999-2002. Penerjemah: E. Setiyawati A. Amandemen UUD 1945: Antara Mitos dan Pembongkaran. Bandung: PT. Mizan Pustaka, 2007. 
Isra, Saldi. Kekuasaan dan Perilaku Korupsi: Catatan Hukum. Jakarta: Penerbit Buku Kompas, 2009.

Jemadu, Aleksius. Politik Global dalam Teori \& Praktik. Yogyakarta: Graha Ilmu, 2008.

Marbun, Rocky. Kiat Jitu Menyelesaikan Kasus Hukum. Jakarta: Visimedia, 2011.

Pusat Penelitian Politik. Democracy Pilkada. Jakarta: LIPI, 2007.

Sasono, Adi. Rakyat Bangkit Bangun Martabat. Tangerang: Pustaka Alvabet dan Dewan Koperasi Indonesia (Dekopin), 2008.

Subekti, Valina Singka. Dinamika Konsolidasi Demokrasi: Dari Ide Pembaruan Sistem Politik hingga ke Praktik Pemerintahan Demokratis. Jakarta: Yayasan Pustaka Obor Indonesia, 2015.

Sudjito. Ilmu Hukum Holistik: Studi untuk Memahami Kompleksitas dan Pnegaturan Pengelolaan Irigasi. Yogyakarta: Gadjah Mada University Press, 2014.

S.J., Budi Susanto (ed). Politik \& Postkolonialitas di Indonesia. Yogyakarta: Kanisius, 2003.

Undang-Undang No. 3 Tahun 2009 tentang Mahkamah Agung. Undang-Undang No. 8 Tahun 2011 Tentang Mahkamah Konstitusi. Undang-Undang Republik Indonesia Nomor 12 Tahun 2011 Tentang Pembentukan Peraturan Perundang-Undangan. YLBHI dan PSHK. Panduan Bantuan Hukum di Indonesia: Pedoman Anda Memahami dan Menyelesaikan Hukum. Cetakan Kedua. Jakarta: YLBHI, 2007.

Yuliartini, Ni Made Ari dan Anak Agung Sri Utari, "Partisipasi Masyarakat dalam Pembentukan Peraturan Daerah", Jurnal Kertha Patrika, Vol. 33 No. 1 (Januari 2008). 